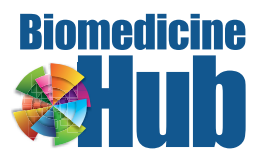

\title{
Trends in Gene Expression Profiling for Prostate Cancer Risk Assessment: A Systematic Review
}

\author{
Zhaoyi Chen $^{a} \quad$ Travis Gerke $^{b} \quad$ Victoria Bird $^{c} \quad$ Mattia Prosperi ${ }^{a}$ \\ a Department of Epidemiology, College of Public Health and Health Professions, College \\ of Medicine, University of Florida, Gainesville, FL, b Moffitt Cancer Center, Tampa, FL, and \\ 'Department of Urology, College of Medicine, University of Florida, Gainesville, FL, USA
}

\section{What Is It about?}

We conducted a qualitative review on gene expression profiling in tissue-based prostate cancer research, with a focus on biotechnology development and gene discovery. The advancing technology allows researchers to conduct studies on a larger scale, and more focused targeting was observed in more recent studies. However, inconsistencies in direction of association between genes and prostate cancer outcomes were also observed between studies, which warrant the execution of validation studies and meta-analyses. Future research can also focus on investigating the link between risk loci and gene expression, and address the discrepancy in risk of prostate cancer among different groups

\section{Keywords}

Gene expression profiling · Prostate cancer - Experimental platform development ·

Gene discovery

\section{Abstract}

Objectives: The aim of the study is to review biotechnology advances in gene expression profiling on prostate cancer ( $\mathrm{PCa}$ ), focusing on experimental platform development and gene discovery, in relation to different study designs and outcomes in order to understand how they can be exploited to improve PCa diagnosis and clinical management. Methods: We conducted a systematic literature review on gene expression profiling studies through PubMed/ MEDLINE and Web of Science between 2000 and 2016. Tissue biopsy and clinical gene profiling studies with different outcomes (e.g., recurrence, survival) were included. Results: Over 3,000 papers were screened and 137 full-text articles were selected. In terms of technology used, microarray is still the most popular technique, increasing from 50 to $70 \%$ between 2010 and 2015, but there has been a rise in the number of studies using RNA sequencing (13\% in 2015). Sample sizes have increased, as well as the number of genes that can be screened all at once, but we have also observed more focused targeting in more recent studies. Qualita- 
tive analysis on the specific genes found associated with PCa risk or clinical outcomes revealed a large variety of gene candidates, with a few consistent cross-studies. Conclusions: The last 15 years of research in gene expression in PCa have brought a large volume of data and information that has been decoded only in part, but advancements in high-throughput sequencing technology are increasing the amount of data that can be generated. The variety of findings warrants the execution of both validation studies and meta-analyses. Genetic biomarkers have tremendous potential for early diagnosis of PCa and, if coupled with other diagnostics (e.g., imaging), can effectively be used to concretize less-invasive, personalized prediction of PCa risk and progression.

(C) 2017 The Author(s)

Published by S. Karger AG, Basel

\section{Introduction}

Prostate cancer (PCa) is the most common non-skin cancer and the leading cause of cancer-related death among men in the United States and other developed countries [1]. Although the incidence of PCa has declined recently due to changes in screening recommendations, it still poses a substantial public health burden; it is estimated there will be 180,890 new PCa cases and 26,120 PCa deaths in 2016 in the United States [1]. With such a health impact, it is important to develop "precision medicine" approaches to individualized PCa diagnosis and prediction of PCa outcomes. Genetic background has been demonstrated to contribute to PCa onset, with an estimated $58 \%$ of the risk of PCa explained by heritable factors [2]. To complement the information provided by germline variation, many recent studies have sought novel gene expression markers to help in all phases of the cancer patient spectrum, from early detection to progression, response to procedures, and survival. Recent advances in multiplexing technologies, from microarrays to high-throughput next-generation sequencing (NGS), allow expression quantification of multiple genes, which, alongside other -omics technologies, can facilitate understanding the biological mechanisms of PCa towards the development of personalized prediction models and tools.

Microarray analysis was introduced as a standard tool of gene expression profiling and transcriptome analysis a decade ago. Microarray technology uses sequence-specific probe hybridization and fluorescence detection to measure gene expression levels, and it provides a comprehensive view of gene expression profiles in biological samples. However, microarray analysis requires a reference genome and transcriptome, and is thus prone to limited detection range and high noise level [3]. After the widespread introduction of NGS technology, RNA sequencing (RNA-Seq) has emerged as a robust tool to generate information on transcriptome or transcribed regions. NGS techniques feature a massive parallelization of the sequencing process that yields a much higher volume of information. Compared to microarrays, RNA-Seq can offer significant advantages in terms reproducibility, throughput, and resolution, and therefore is becoming the preferred experimental platform for gene expression and transcriptome analysis [4].

In the past 2 decades, there has been a plethora of studies examined gene expression profiles in PCa utilizing microarrays, RNA-Seq, and other techniques on a variety of study designs and settings: thousands of genes have been identified to be expressed abnormally in PCa cells, tissues, or animal models with PCa. The PCa outcomes of interest have varied as well, from the comparison of cancerous versus non-cancerous tissues, to PCa recurrence, to metastasis, and to survival.

In the present study, we perform a systematic review of peer-reviewed scientific works investigating gene expression in PCa published between 2000 and 2016, focusing on population-based or human tissue study settings. We chose this time frame because the "modern 


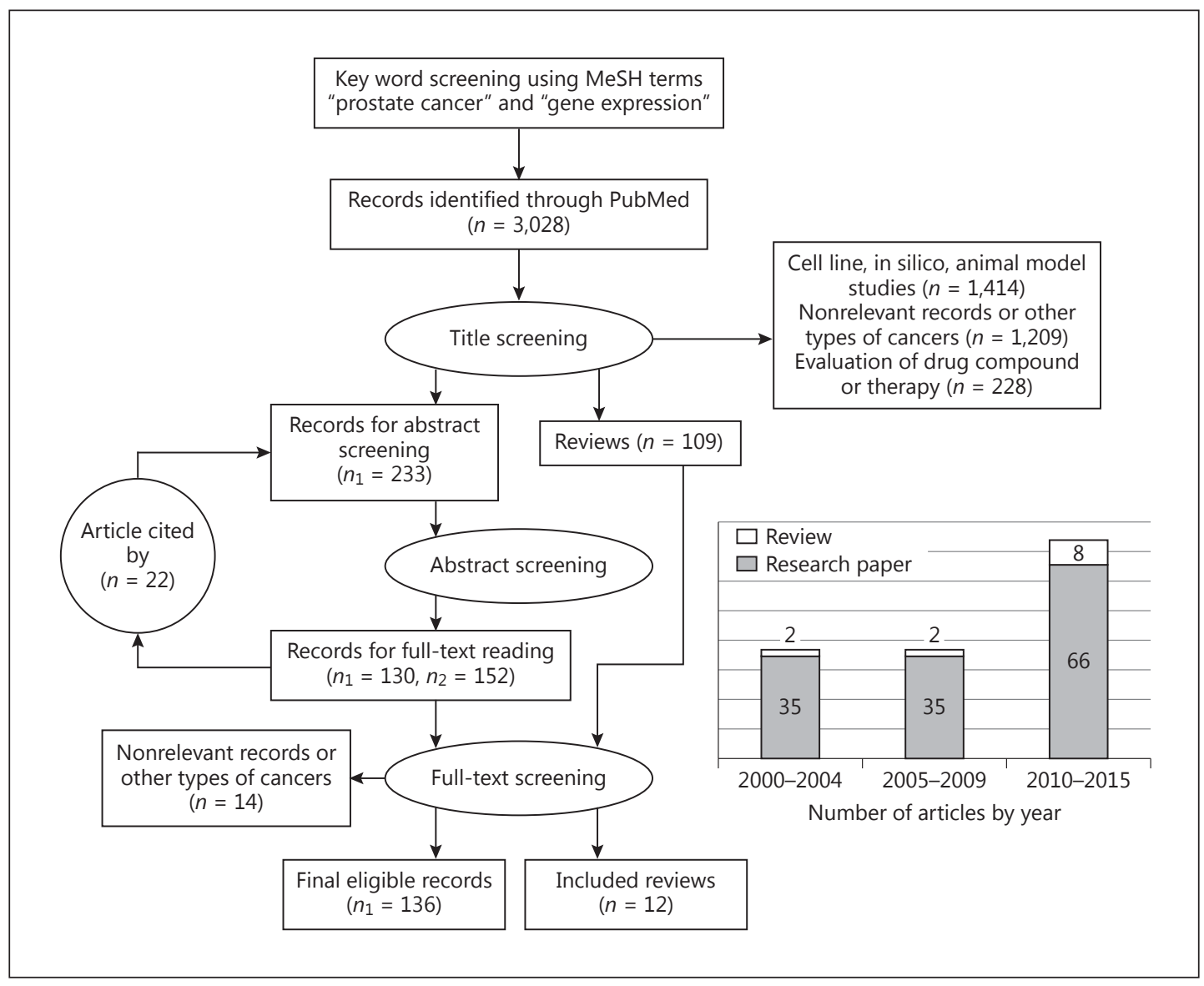

Fig. 1. Flow chart presenting the steps of literature search and selection of articles.

era" of microarray technology started at the end of the 1990s [5]. Our goal is to assess findings and trends in gene expression profiling for PCa risk assessment, and provide insights on which genetic elements of PCa appear to be the most promising to pursue for diagnosis and clinical management. We will not discuss here the appropriateness of analytical methods, nor perform a quantitative meta-analysis on the gene profiles.

\section{Methods}

We conducted the systematic literature review according to the Preferred Reporting Item for Systematic Reviews and Meta-Analyses (PRISMA) guideline [6]. The process of identification and selection of papers is presented as a flowchart in Figure 1. We performed a PubMed/MEDLINE search of all articles from 2000 to June 2016 using the MeSH terms "prostate cancer" and "gene expression" or "gene expression profiling" together. We also performed a search in Web of Science using the topics "prostate cancer" and "gene expression" or "gene expression profiling" together. Articles in English were included and prioritized according to the following criteria: studies using human tissue samples, human clinical studies, studies with gene expression profiling as the main predictor, and studies with biological and clinical outcomes. To ensure the completeness of our literature review, we 


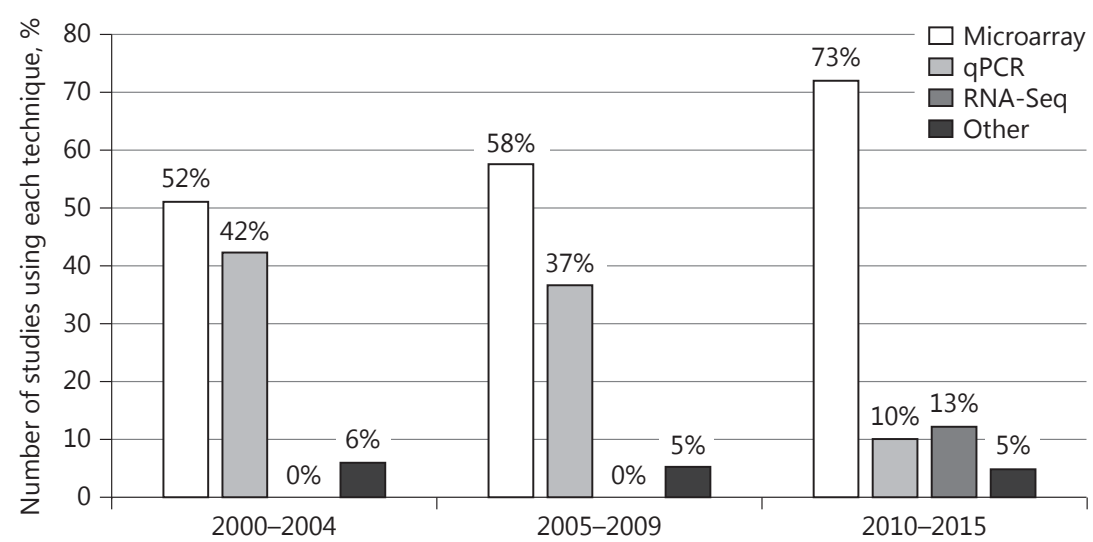

Fig. 2. Technology used for measuring gene expression in prostate cancer studies, broken down by calendar year. qPCR, qualitative PCR; RNA-Seq, RNA sequencing.

adopted a feedback search strategy, looking at papers cited by included studies, which were then examined for eligibility. Articles were ranked independently by 2 scientists in our team with a third scientist's vote in case of disagreement regarding inclusion. Reviews were analyzed separately.

\section{Results}

After literature screening, 12 reviews [7-18] and 137 research papers [19-155] were included in the final phase of full-text reading and review of findings. Included articles, as expected, exhibited large diversities in the experimental techniques used, the study settings and the sample sizes, the definition of PCa outcomes, the number of genes analyzed, and the genes identified as differentially expressed.

We first examined the trends in experimental techniques used for gene expression measurement over the years. Figure 2 illustrates the proportion of techniques used among original papers by 5-year calendar periods. Microarray is still the major technique being used for PCa gene expression studies, increasing from 50 to $70 \%$ between 2010 and 2015. The use of qualitative PCR and other methods has decreased, accompanied by a rise in the number of RNA-Seq studies in more recent years since the beginning of the NGS era, specifically $13 \%$ between 2010 and 2015.

Figure 3 shows the trend of study sample size (in terms of observation units, either number of tissues or subjects) per study. A significant increase in sample size is observed, especially for 2010-2015, possibly due to reduction in costs of experimental techniques as well as other improvements in biomedical research. Another benefit of the advanced technology and reduced cost is the possibility of developing gene panels to predict PCa occurrence and outcomes by screening a huge volume of genes or the whole genome. There were 7 studies from 2010 to 2015 that screened 1.4 million probe sets and identified gene panels associated with PCa occurrence [75, 79, 80, 81, 87, 98, 111], while there was only 1 study of a similar scale in between 2005 and 2009 [68]. After removing studies that developed gene panels, we observed a significant decrease in the number of genes screened per study (more than 90,000 in $2000-2004$ to 5,500 in $2005-2009$, to 1,500 in $2010-2015$ ), which may 


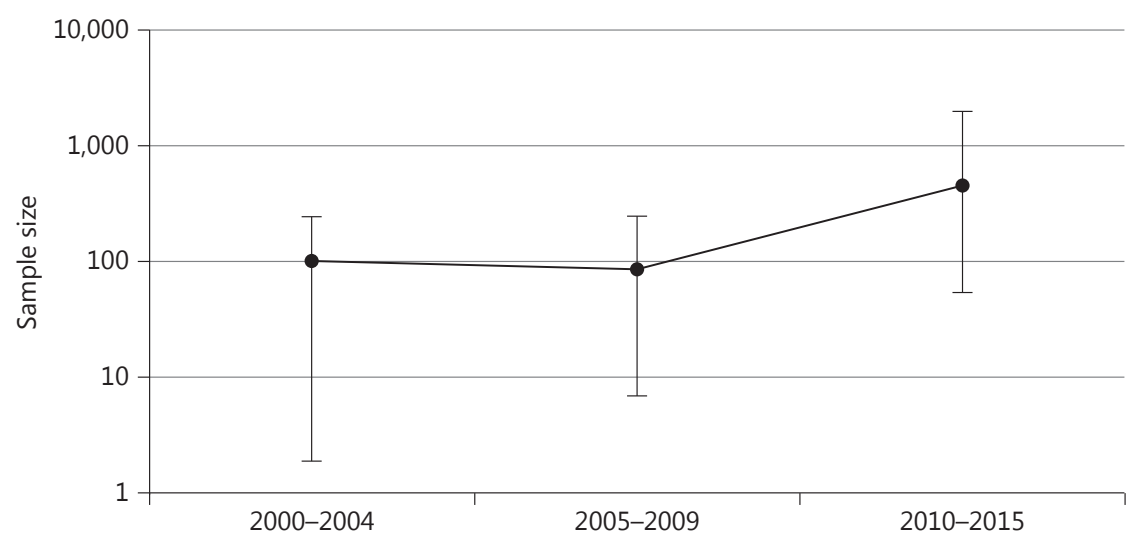

Fig. 3. Sample size trends by year.

indicate that gene expression studies in PCa have been undergoing a more focused targeting. A large proportion of included studies focused only on one target gene or one type of genes, and since we only included tissue-based PCa studies, many of them were trying to explore the expression pattern of previous identified genes from cell line studies or genes identified from other cancers.

Overall, $62 \%$ of the studies investigated whether the target genes have abnormal expression activities in PCa tissues. Genes that regulate apoptosis were examined intensively. For example, Iacopino et al. [55] found that BCL-2 were overexpressed in PCa tissues compared to BPH tissue, while some other apoptosis-related genes (e.g., FAS, c-Myc) were nondifferentially expressed. Furthermore, Sethi et al. [88] showed that BAG-5, a BCL2-associated athanogene, is overexpressed in PCa, and that BAG-5 also has inhibition on apoptosis in cell studies. In addition to apoptosis-related genes observed in other types of cancer, the development and progression of PCa has also been demonstrated to be androgen related - many studies have investigated the expression of androgen-regulated genes and showed that they may play an important role in PCa progression. For example, MYC and NCOA2 were identified as major contributors to the androgen receptor signaling pathway and exhibit higher expression in prostate tumors [72]. The overexpression of AGR-2 was also demonstrated by multiple studies as well as its association with shorter survival and higher Gleason score $[59,77]$.

In addition, among all tissue-based PCa studies, we looked at the disease progression outcomes, including recurrence, metastasis, and survival. The ERG gene, as a highly prevalent fusion partner in $\mathrm{PCa}$, also showed a positive association with both a high Gleason score and short survival in several different study settings $[84,85,106]$. Multiple studies have demonstrated that AMACR, a gene that encodes an enzyme that functions in breaking down fatty acids and certain toxic compounds, is overexpressed in groups with adverse outcomes [31, $47,61,111]$. Other notable genes associated with poor prognostic outcomes include AGR-2, IGFBP-3, and MUC-1 [21, 34, 48, 56, 59, 62, 67, 77].

Figure 4 gives a qualitative description of the most frequently mentioned genes in the studies of interest, both reviews and original papers, with respect to different outcomes. The 3 circles represent different PCa outcomes that are commonly examined in gene expression analysis; the genes included in each circle are genes positively associated with or overexpressed for the specified outcome. Genes in intersections were associated multiple outcomes. 
Fig. 4. Most frequently discussed prostate cancer genes by study outcome.

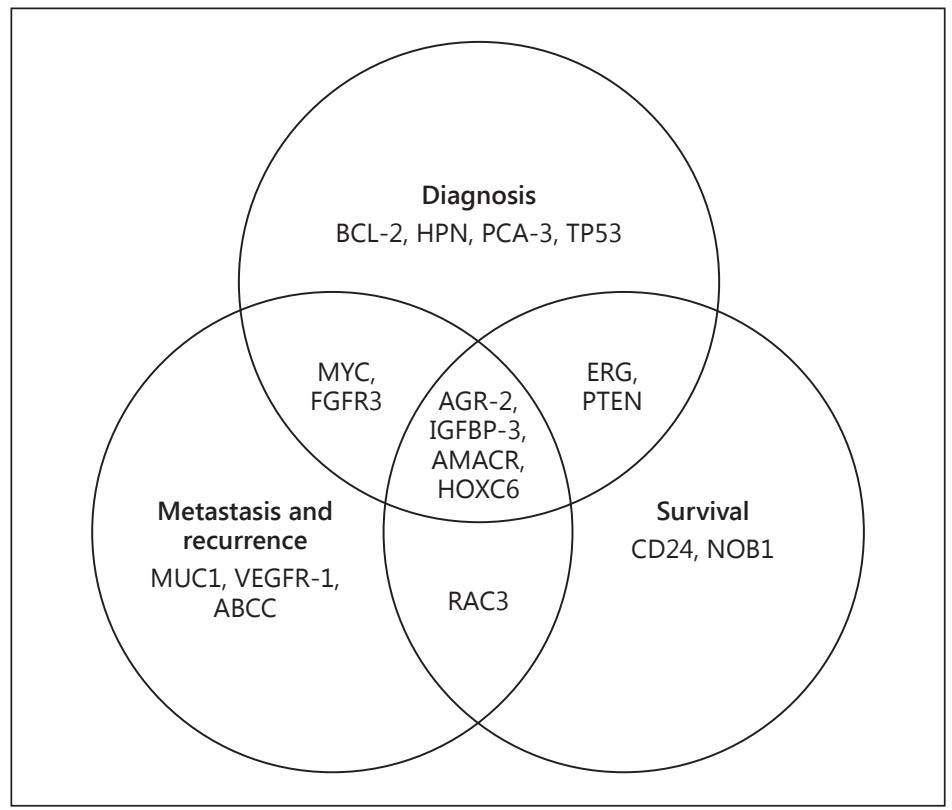

Note that the diagram does not account for risk/hazard or sample size, and it is not the result of a quantitative meta-analysis.

Interestingly, we did not find a striking overlap among studies or among different outcomes. For example, among the 400 genes identified to be significantly overexpressed in PCa tissues in a 2001 study by Welsh et al. [20], only a few were examined in further studies. Eight studies performed large-scale or whole-genome gene expression analysis and identified thousands of differentially expressed genes, which highlights a potentially complex scenario of gene interactions [21, 24, 29, 36, 61, 81, 86, 91]. In addition, discrepant results were observed from different studies. In a case-control study conducted by Mao et al. [60], similar expression scores of VEGFR-1 were observed in patients with and without recurrence, indicating its expression was not associated with the risk of recurrence; however, 2 more recent studies showed conflicting results and suggested VEGFR-1 was overexpressed in recurrence cases $[89,108]$. Of all those genes, a large proportion is in need of further investigation in terms of coexpression analysis and roles in PCa development.

Recently, researchers started to use a combination of multiple genes to build expression panels to predict PCa outcomes. Some works used prior knowledge by including already identified genes and key PCa carcinogenic pathways $[68,80,87,106]$, while others screened ex novo thousands of genes and filtered the most significant ones [34, 49, 67, 69, 79, 98, 111]. For example, Penney et al. [76] analyzed more than 6,000 genes using Gene Set Enrichment Analysis (GSEA) and generated a 157-gene panel that showed improved prediction of survival among PCa cases with a Gleason score of 7. Cheville et al. [65] identified a 4-gene expression panel from a set of previously identified genes to predict survival under a cohort study setting.

\section{Discussion}

We performed a systematic review of human tissue-based gene expression analysis in PCa from 2000 to 2016, identifying 137 original research articles and 12 reviews focused on differential expression in PCa tissue and disease progression outcomes. 
For more than 15 years, sample sizes of studies have been increasing, but the size of gene sets has varied considerably. The technology employed the most remains the microarray, but RNA-Seq by means of NGS is on the rise. However, certain challenges have prevented wide use of NGS in PCa gene expression research. For example, formalin-fixed paraffin-embedded (FFPE) tissues samples are often used in PCa research because a long follow-up is needed. FFPE samples can be conveniently stored at room temperature, are cost-effective, and work well for immunohistochemical staining and morphology analyses. Since FFPE is widespread, there are numerous archives from which samples can be selected. On the other hand, formalin is toxic, FFPE protocols are not standardized, and they are usually not well suited for molecular analysis. FFPE tissues consist of fragmented or cross-linked DNA and may be damaged over time, or reduce the quantity of DNA available, and will reduce the performance of NGS [156].

Thousands of genes have been associated with PCa tissue, status, or cancer progression outcomes, providing the possibility of identifying valuable biomarkers for PCa. A portion of them has been confirmed in multiple studies, and only a few have been characterized thoroughly. Qualitatively, we observed a large degree of heterogeneity, discrepancies of expression among different studies, and poor consistency across different PCa outcomes. A meta-analysis may provide a clearer picture of the independent effect of single gene expression on the PCa outcomes.

Given the large number of gene findings, analysis of coexpression is warranted: highthroughput technology and larger population size allows the development of multivariable risk prediction scores, and the execution of clustering or net discovery algorithms to better characterize mechanisms of joint gene expressions in PCa and metabolic pathways.

Despite the limitations highlighted, gene expression studies can provide abundant information and opportunities for a better understanding of PCa and potential clinical uses of gene-based biomarkers. For example, a novel PCa screening test has been developed commercially based on gene expression profiling. The test, with the brand name Prolaris, utilizes a CCP (cell cycle proliferation) score assessing the RNA expression of 46 genes to make predictions on progression and aggressiveness of PCa [80]. Another commercially available test named GenomeDX uses a 22-gene signature to predict PCa metastasis after surgery, and has shown good discrimination in detecting men who are at risk for metastatic PCa [98].

As demonstrated by studies we reviewed, strategic gene expression profiling is able to encourage recognition and treatment of the PCa patient population, especially with the combination of other new techniques such as prostate magnetic resonance imaging (MRI). The incorporation of prostate MRI can improve patient risk stratification and treatment modality, including active surveillance and monitoring. Prostate MRI has a role in discontinuation of patients in active surveillance due to changes detected in tumor size and characteristics [157]. Together, new technological advances in radiological modalities and incorporation of individualized genetic profiling will help identify patients in different risk stratification and promote a better plan of management of their disease, with possible prevention of overtreatment and its consequential risks and side effects.

Nonetheless, there are open challenges for developing risk prediction scores based on gene expression. As Sboner et al. [155] and coworkers pointed out, the performance of predictive models based on molecular profiling are not as good as those using clinical variables only; in other words, the prostate-specific antigen level and the Gleason score are still the best indicator and predictor of PCa progression as compared to scores based on gene expression profiles. However, PCa is a highly heterogeneous cancer; even the Gleason score is subject to variation within an individual tissue sample. It is likely that a combination of clinical, gene expression, and other -omics domains will help explain the remaining variance. Furthermore, the end points of interests for PCa gene expression studies are multiple: there are tissue-based case-control studies, and there are clinical outcomes including severity, 
recurrence, metastasis, and survival. Even tissue-based studies are not necessarily optimal for inferring (early) predictors of PCa onset. On the other hand, several genome-wide association studies looked at single nucleotide polymorphisms (SNPs) and identified risk scores based on SNPs comparing men who were diagnosed with PCa versus those who were not [158-160]. It will be useful to study the link between risk SNPs or loci and gene expression to find out if risk SNPs for incidence relate to gene expression candidates for clinical outcomes such as survival, and help establish a complete collection of biomarkers to make diagnostic and prognostic predictions. Expression quantitative trait loci studies have attempted to address this issue; however, there are a very limited number of such studies because overlapping information on SNPs, gene expression, and long-term outcomes are required. In a recent expression quantitative trait loci study, researchers examined 47 risk SNPs in a large case-control setting - only 8 of them were associated with PCa-specific mortality with relatively small magnitudes of the associations [160]. Thus, further investigations are still needed in this area.

Finally, it has been well established that there are great differences in risk of PCa among different races or ethnicity groups, and a few gene expression studies have observed discrepancies in race. For example, Hernandez et al. [59] showed that IGF-1 and IGFBP-3 were not associated with PCa in the African-American population, while other studies have shown the opposite in the Caucasian population. The number of studies that examined gene expression patterns among different races or ethnicity groups is limited, and future studies could yield valuable information on the racial disparities of $\mathrm{PCa}$.

\section{Conclusion}

The last 15 years of research in gene expression in PCa have brought a lot of data and information that has been decoded only in part. Combining laboratory and clinical variables, including the addition of MRI technology, with novel predictors found in different -omics domains may help in covering the residual unexplained variance and differences not only at the racial/ethnicity level, but also at the individual and specific outcome level. Advancements in sequencing technology and big data analytics will probably increase the amount of data generated in the next years, but will also allow accurate meta-analyses and apply more complex data mining techniques to identify biomarkers for early diagnosis of PCa and personalized prediction of disease progression.

\section{References}

1 Siegel RL, Miller KD, Jemal A: Cancer statistics, 2015. CA Cancer J Clin 2015; 65:5-29.

-2 Hjelmborg JB, Scheike T, Holst K, Skytthe A, Penney KL, Graff RE, Pukkala E, Christensen K, Adami HO, Holm NV, Nuttall E, Hansen S, Hartman M, Czene K, Harris JR, Kaprio J, Mucci LA: The heritability of prostate cancer in the Nordic Twin Study of Cancer. Cancer Epidemiol Biomarkers Prev 2014;23:2303-2310.

3 Wang Z, Gerstein M, Snyder M: RNA-Seq: a revolutionary tool for transcriptomics. Nat Rev Genet 2009;10: 57-63.

4 Wolf JB: Principles of transcriptome analysis and gene expression quantification: an RNA-seq tutorial. Mol Ecol Resour 2013;13:559-572.

5 Bumgarner R: Overview of DNA microarrays: types, applications, and their future. Curr Protoc Mol Biol 2013; 101:22.1.1-22.1.11.

-6 Moher D, Liberati A, Tetzlaff J, Altman DG; The PRISMA Group: Preferred reporting items for systematic reviews and meta-analyses: the PRISMA statement. PLoS Med 2009;6:e1000097.

7 Kumar B, Lupold S: MicroRNA expression and function in prostate cancer: a review of current knowledge and opportunities for discovery. Asian J Androl 2016;18:559-567.

-8 Nelson PS: Predicting prostate cancer behavior using transcript profiles. J Urol 2004;172:S28. 
-9 Reddy G, Balk S: Clinical utility of microarray-derived genetic signatures in predicting outcomes in prostate cancer. Clin Genitourin Cancer 2006;5:187-189.

10 Kim J, Yu J: Interrogating genomic and epigenomic data to understand prostate cancer. Biochim Biophys Acta 2012;1825:186.

11 Choudhury AD, Eeles R, Freedland SJ, Isaacs WB, Pomerantz MM, Schalken JA, Tammela TL, Visakorpi T: The role of genetic markers in the management of prostate cancer. Eur Urol 2012;62:577-587.

12 Hudson BD, Kulp KS, Loots GG: Prostate cancer invasion and metastasis: insights from mining genomic data. Brief Funct Genomics 2013;12:397-410.

-13 Chen J, Zhang D, Yan W, Yang D, Shen B: Translational bioinformatics for diagnostic and prognostic prediction of prostate cancer in the next-generation sequencing era. Biomed Res Int 2013;901578.

14 Tolkach Y, Imkamp F, Godin K, Poppel V: Clinically relevant genetic characterization of prostate tumors: how close are we to the goal? Korean J Urol 2015;56:90.

$\checkmark 15$ Nguyen HG, Welty CJ, Cooperberg MR: Diagnostic associations of gene expression signatures in prostate cancer tissue. Curr Opin Urol 2015;25:65-70.

16 Boström PJ, Bjartell AS, Catto JW, Eggener SE, Lilja H, Loeb S, Schalken J, Schlomm T, Cooperberg MR: Genomic predictors of outcome in prostate cancer. Eur Urol 2015;68:1033-1044.

17 Wang YL, Wu S, Jiang B, Yin FF, Zheng SS, Hou SC: Role of microRNAs in prostate cancer pathogenesis. Clin Genitourin Cancer 2015;13:261-270.

18 Yoshimura R, Sano H, Masuda C, Kawamura M, Tsubouchi Y, Chargui J, Yoshimura N, Hla T, Wada S: Expression of cyclooxygenase-2 in prostate carcinoma. Cancer 2000;89:589-596.

19 Xu LL, Stackhouse BG, Florence K, Zhang W, Shanmugam N, Sesterhenn IA, Zou Z, Srikantan V, Augustus M, Roschke V, Carter K, McLeod DG, Moul JW, Soppett D, Srivastava S: PSGR, a novel prostate-specific gene with homology to a G protein-coupled receptor, is overexpressed in prostate cancer. Cancer Res 2000;60:65686572.

20 Welsh JB, Sapinoso LM, Su AI, Kern SG, Wang-Rodriguez J, Moskaluk CA, Frierson HF Jr, Hampton GM: Analysis of gene expression identifies candidate markers and pharmacological targets in prostate cancer. Cancer Res 2001;61:5974-5978.

-21 Gnanapragasam VJ, Leung HY, Pulimood AS, Neal DE, Robson CN: Expression of RAC 3, a steroid hormone receptor co-activator in prostate cancer. Br J Cancer 2001;85:1928-1936.

22 Magee JA, Araki T, Patil S, Ehrig T, True L, Humphrey PA, Catalona WJ, Watson MA, Milbrandt J: Expression profiling reveals hepsin overexpression in prostate cancer. Cancer Res 2001;61:5692-5696.

-23 Luo J, Duggan DJ, Chen Y, Sauvageot J, Ewing CM, Bittner ML, Trent JM, Isaacs WB: Human prostate cancer and benign prostatic hyperplasia molecular dissection by gene expression profiling. Cancer Res 2001;61:46834688.

24 Ito T, Tachibana M, Yamamoto S, Nakashima J, Murai M: Expression of estrogen receptor (ER-alpha and ERbeta) mRNA in human prostate cancer. Eur Urol 2001;40:557.

25 Fujimoto N, Mizokami A, Harada S, Matsumoto T: Different expression of androgen receptor coactivators in human prostate. Urology 2001;58:289-294.

-26 Dasari VK, Goharderakhshan RZ, Perinchery G, Li LC, Tanaka Y, Alonzo J, Dahiya R: Expression analysis of Y chromosome genes in human prostate cancer. J Urol 2001;165:1335-1341.

-27 Figueroa JA, De Raad S, Speights VO, Rinehart JJ: Gene expression of insulin-like growth factors and receptors in neoplastic prostate tissues: correlation with clinico-pathological parameters. Cancer Invest 2001;19: 28-34.

28 Waghray A, Schober M, Feroze F, Yao F, Virgin J, Chen YQ: Identification of differentially expressed genes by serial analysis of gene expression in human prostate cancer. Cancer Res 2001;61:4283-4286.

-29 Luo J, Zha S, Gage WR, Dunn TA, Hicks JL, Bennett CJ, Ewing CM, Platz EA, Ferdinandusse S, Wanders RJ, Trent JM, Isaacs WB, De Marzo AM: $\alpha$-Methylacyl-CoA racemase: a new molecular marker for prostate cancer. Cancer Res 2002;62:2220-2226.

30 Koh E, Noda T, Kanaya J, Namiki M: Differential expression of 17beta-hydroxysteroid dehydrogenase isozyme genes in prostate cancer and noncancer tissues. Prostate 2002;53:154-159.

-31 Ide H, Seligson DB, Memarzadeh S, Xin L, Horvath S, Dubey P, Flick MB, Kacinski BM, Palotie A, Witte ON: Expression of colony-stimulating factor 1 receptor during prostate development and prostate cancer progression. Proc Natl Acad Sci USA 2002;99:14404-14409.

32 Singh D, Febbo PG, Ross K, Jackson DG, Manola J, Ladd C, Tamayo P, Renshaw AA, D’Amico AV, Richie JP, Lander ES, Loda M, Kantoff PW, Golub TR, Sellers WR: Gene expression correlates of clinical prostate cancer behavior. Cancer Cell 2002;1:203-209.

-33 Bièche I, Latil A, Parfait B, Vidaud D, Laurendeau I, Lidereau R, Cussenot O, Vidaud M: CGA gene (coding for the alpha subunit of glycoprotein hormones) overexpression in ER alpha-positive prostate tumors. Eur Urol 2002;41:335-341.

-34 LaTulippe E, Satagopan J, Smith A, Scher H, Scardino P, Reuter V, Gerald WL: Comprehensive gene expression analysis of prostate cancer reveals distinct transcriptional programs associated with metastatic disease. Cancer Res 2002;62:4499-4506.

- 35 Ishiguro H, Uemura H, Fujinami K, Ikeda N, Ohta S, Kubota Y: 55 kDa nuclear matrix protein (nmt55) mRNA is expressed in human prostate cancer tissue and is associated with the androgen receptor. Int J Cancer 2003; 105:26-32. 
-36 Stephan C, Yousef GM, Scorilas A, Jung K, Jung M, Kristiansen G, Hauptmann S, Bharaj BS, Nakamura T, Loening SA, Diamandis E: Quantitative analysis of kallikrein 15 gene expression in prostate tissue. J Urol 2003;169: 361-364.

-37 Henshall SM, Afar DE, Hiller J, Horvath LG, Quinn DI, Rasiah KK, Gish K, Willhite D, Kench JG, Gardiner-Garden M, Stricker PD, Scher HI, Grygiel JJ, Agus DB, Mack DH, Sutherland RL: Survival analysis of genome-wide gene expression profiles of prostate cancers identifies new prognostic targets of disease relapse. Cancer Res 2003; 63:4196-4203.

-38 Balcerczak E, Mirowski M, Sasor A, Wierzbicki R: Expression of p65, DD3 and c-erbB2 genes in prostate cancer. Neoplasma 2003;50:97-101.

-39 Stadlmann S, Moser PL, Pollheimer J, Steiner P, Krugmann J, Dirnhofer S, Mikuz G, Margreiter R, Amberger A: Heparanase-1 gene expression in normal, hyperplastic and neoplastic prostatic tissue. Eur J Cancer 2003;39: 2229-2233.

40 Savinainen KJ, Saramäki OR, Linja MJ, Bratt O, Tammela TL, Isola JJ, Visakorpi T: Expression and gene copy number analysis of ERBB2 oncogene in prostate cancer. Am J Pathol 2002;160:339-345.

-41 Kristiansen G, Pilarsky C, Pervan J, Stürzebecher B, Stephan C, Jung K, Loening S, Rosenthal A, Dietel M: CD24 expression is a significant predictor of PSA relapse and poor prognosis in low grade or organ confined prostate cancer. Prostate 2004;58:183-192.

-42 Jerónimo C, Henrique R, Oliveira J, Lobo F, Pais I, Teixeira MR, Lopes C: Aberrant cellular retinol binding protein 1 (CRBP1) gene expression and promoter methylation in prostate cancer. J Clin Pathol 2004;57:872876.

-43 Fenic I, Franke F, Failing K, Steger K, Woenckhaus J: Expression of PTEN in malignant and non-malignant human prostate tissues: comparison with p27 protein expression. J Pathol 2004;203:559-566.

-44 Yu YP, Landsittel D, Jing L, Nelson J, Ren B, Liu L, McDonald C, Thomas R, Dhir R, Finkelstein S, Michalopoulos G, Becich M, Luo JH: Gene expression alterations in prostate cancer predicting tumor aggression and preceding development of malignancy. J Clin Oncol 2004;22:2790-2799.

-45 Lapointe J, Li C, Higgins JP, van de Rijn M, Bair E, Montgomery K, Ferrari M, Egevad L, Rayford W, Bergerheim U, Ekman P, DeMarzo AM, Tibshirani R, Botstein D, Brown PO, Brooks JD, Pollack JR: Gene expression profiling identifies clinically relevant subtypes of prostate cancer. Proc Natl Acad Sci USA 2004;101:811-816.

-46 Glinsky GV, Glinskii AB, Stephenson AJ, Hoffman RM, Gerald WL: Gene expression profiling predicts clinical outcome of prostate cancer. J Clin Invest 2004;113:913-923.

47 McAlhany SJ, Ayala GE, Frolov A, Ressler SJ, Wheeler TM, Watson JE, Collins C, Rowley DR: Decreased stromal expression and increased epithelial expression of WFDC1/ps20 in prostate cancer is associated with reduced recurrence-free survival. Prostate 2004;61:182-191.

48 Shariat SF, Menesses-Diaz A, Kim IY, Muramoto M, Wheeler TM, Slawin KM: Tissue expression of transforming growth factor-beta1 and its receptors: correlation with pathologic features and biochemical progression in patients undergoing radical prostatectomy. Urology 2004;63:1191-1197.

-49 Santagata S, Demichelis F, Riva A, Varambally S, Hofer MD, Kutok JL, Kim R, Tang J, Montie JE, Chinnaiyan AM, Rubin MA, Aster JC: JAGGED1 expression is associated with prostate cancer metastasis and recurrence. Cancer Res 2004;64:6854-6857.

-50 Kristiansen G, Pilarsky C, Wissmann C, Kaiser S, Bruemmendorf T, Roepcke S, Dahl E, Hinzmann B, Specht T, Pervan J, Stephan C, Loening S, Dietel M, Rosenthal A: Expression profiling of microdissected matched prostate cancer samples reveals CD166/MEMD and CD24 as new prognostic markers for patient survival. J Pathol 2005;205:359-376.

-51 Koizumi F, Noguchi Y, Saika T, Nakagawa K, Sato S, Eldib AM, Nasu Y, Kumon H, Nakayama E: XAGE-1 mRNA expression in prostate cancer and antibody response in patients. Microbiol Immunol 2005;49:471-476.

-52 Stephenson AJ, Smith A, Kattan MW, Satagopan J, Reuter VE, Scardino PT, Gerald WL: Integration of gene expression profiling and clinical variables to predict prostate carcinoma recurrence after radical prostatectomy. Cancer 2005;104:290-298.

53 Cozzi PJ, Wang J, Delprado W, Perkins AC, Allen BJ, Russell PJ, Li Y: MUC1, MUC2, MUC4, MUC5AC and MUC6 expression in the progression of prostate cancer. Clin Exp Metastasis 2005;22:565-573.

54 Koh MS, Ittmann M, Kadmon D, Thompson TC, Leach FS: CDC4 gene expression as potential biomarker for targeted therapy in prostate cancer. Cancer Biol Ther 2006;5:78-83.

-55 Iacopino F, Angelucci C, Lama G, Zelano G, La Torre G, D’Addessi A, Giovannini C, Bertaccini A, Macaluso MP, Martorana G, Sica G: Apoptosis-related gene expression in benign prostatic hyperplasia and prostate carcinoma. Anticancer Res 2006;26:1849-1854.

-56 Zhang Y, Forootan SS, Liu D, Barraclough R, Foster CS, Rudland PS, Ke Y: Increased expression of anterior gradient-2 is significantly associated with poor survival of prostate cancer patients. Prostate Cancer Prostatic Dis 2007;10:293-300.

-57 Fromont G, Vallancien G, Validire P, Levillain P, Cussenot O: BCAR1 expression in prostate cancer: association with 16q23 LOH status, tumor progression and EGFR/KAI1 staining. Prostate 2007;67:268-273.

-58 Chandran UR, Ma C, Dhir R, Bisceglia M, Lyons-Weiler M, Liang W, Michalopoulos G, Becich M, Monzon FA: Gene expression profiles of prostate cancer reveal involvement of multiple molecular pathways in the metastatic process. BMC Cancer 2007;7:64.

-59 Hernandez W, Grenade C, Santos ER, Bonilla C, Ahaghotu C, Kittles RA: IGF-1 and IGFBP-3 gene variants influence on serum levels and prostate cancer risk in African-Americans. Carcinogenesis 2007;28:2154-2159. 
-60 Mao K, Camparo P, Badoual C, Peyromaure M, Delongchamps NB, Vieillefond A, Dinh-Xuan AT: The association of vascular endothelial growth factor receptor-1 with the risk of cancer progression following radical prostatectomy. Oncol Rep 2008;19:171-175.

-61 Leite KR, Mitteldorf CA, Srougi M, Dall'oglio MF, Antunes AA, Pontes J Jr, Camara-Lopes LH: Cdx2, cytokeratin 20 , thyroid transcription factor 1 , and prostate-specific antigen expression in unusual subtypes of prostate cancer. Ann Diagn Pathol 2008;12:260-266.

-62 Feder-Mengus C, Wyler S, Hudolin T, Ruszat R, Bubendorf L, Chiarugi A, Pittelli M, Weber WP, Bachmann A, Gasser TC, Sulser T, Heberer M, Spagnoli GC, Provenzano M: High expression of indoleamine 2,3-dioxygenase gene in prostate cancer. Eur J Cancer 2008;44:2266-2275.

63 Zhang H, Zhang Y, Duan HO, Kirley SD, Lin SX, McDougalWS, Xiao H, Wu CL: TIP30 is associated with progression and metastasis of prostate cancer. Int J Cancer 2008;123:810-816.

64 Nakagawa T, Kollmeyer TM, Morlan BW, Anderson SK, Bergstralh EJ, Davis BJ, Asmann YW, Klee GG, Ballman $\mathrm{KV}$, Jenkins RB: A tissue biomarker panel predicting systemic progression after PSA recurrence post-definitive prostate cancer therapy. PLoS One 2008;3:e2318.

65 Cheville JC, Karnes RJ, Therneau TM, Kosari F, Munz JM, Tillmans L, Basal E, Rangel LJ, Bergstralh E, Kovtun IV, Savci-Heijink CD, Klee EW, Vasmatzis G: Gene panel model predictive of outcome in men at high-risk of systemic progression and death from prostate cancer after radical retropubic prostatectomy. J Clin Oncol 2008;26:3930-3936.

66 Ambs S, Prueitt RL, Yi M, Hudson RS, Howe TM, Petrocca F, Wallace TA, Liu CG, Volinia S, Calin GA, Yfantis HG, Stephens RM, Croce CM: Genomic profiling of microRNA and messenger RNA reveals deregulated microRNA expression in prostate cancer. Cancer Res 2008;68:6162-6170.

67 Lin D, Cui F, Bu Q, Yan C: The expression and clinical significance of GTP-binding RAS-like 3 (ARHI) and microRNA 221 and 222 in prostate cancer. J Int Med Res 2011;39:1870-1875.

68 van der Heul-Nieuwenhuijsen L, Dits NF, Jenster G: Gene expression of forkhead transcription factors in the normal and diseased human prostate. BJU Int 2009;103:1574-1580.

69 Salagierski M, Verhaegh GW, Jannink SA, Smit FP, Hessels D, Schalken JA: Differential expression of PCA3 and its overlapping PRUNE2 transcript in prostate cancer. Prostate 2010;70:70-78.

-70 Celhay 0, Yacoub M, Irani J, Dore B, Cussenot O, Fromont G: Expression of estrogen related proteins in hormone refractory prostate cancer: association with tumor progression. J Urol 2010;184:2172-2178.

71 Ghafouri-Fard S, Ousati AZ, Sabah Golian B, Hasheminasab SM, Modarressi MH: Expression of two testisspecific genes, SPATA19 and LEMD1, in prostate cancer. Arch Med Res 2010;41:195-200.

72 Taylor BS, et al: Integrative genomic profiling of human prostate cancer. Cancer Cell 2010;18:11-22.

73 Goering W, Ribarska T, Schulz WA: Selective changes of retroelement expression in human prostate cancer. Carcinogenesis 2011;32:1484-1492.

74 Bu H, Bormann S, Schäfer G, Horninger W, Massoner P, Neeb A, Lakshmanan VK, Maddalo D, Nestl A, Sültmann $\mathrm{H}$, Cato AC, Klocker H: The anterior gradient 2 (AGR2) gene is overexpressed in prostate cancer and may be useful as a urine sediment marker for prostate cancer detection. Prostate 2011;71:575-587.

-75 Reis ST, Pontes-Júnior J, Antunes AA, Sousa-Canavez JM, Abe DK, Cruz JA, Dall'oglio MF, Crippa A, Passerotti CC, Ribeiro-Filho LA, Viana NI, Srougi M, Leite KR: Tgf- $\beta 1$ expression as a biomarker of poor prognosis in prostate cancer. Clinics (Sao Paulo) 2011;66:1143-1147.

-76 Penney KL, Sinnott JA, Fall K, Pawitan Y, Hoshida Y, Kraft P, Stark JR, Fiorentino M, Perner S, Finn S, Calza S, Flavin R, Freedman ML, Setlur S, Sesso HD, Andersson SO, Martin N, Kantoff PW, Johansson JE, Adami HO, Rubin MA, Loda M, Golub TR, Andrén 0, Stampfer MJ, Mucci LA: mRNA expression signature of Gleason grade predicts lethal prostate cancer. J Clin Oncol 2011;29:2391-2396.

-77 Cuzick J, Swanson GP, Fisher G, Brothman AR, Berney DM, Reid JE, Mesher D, Speights VO, Stankiewicz E, Foster CS, Møller H, Scardino P, Warren JD, Park J, Younus A, Flake DD 2nd, Wagner S, Gutin A, Lanchbury JS, Stone S; Transatlantic Prostate Group: Prognostic value of an RNA expression signature derived from cell cycle proliferation genes in patients with prostate cancer: a retrospective study. Lancet Oncol 2011;12:245-255.

-78 Bălăcescu L, Bălăcescu 0, Crişan N, Fetica B, Petruţ B, Bungărdean C, Rus M, Tudoran 0, Meurice G, Irimie A, Dragoș N, Berindan-Neagoe I: Identifying molecular features for prostate cancer with Gleason 7 based on microarray gene expression profiles. Rom J Morphol Embryol 2011;52:1195-1202.

79 Krohn A, Diedler T, Burkhardt L, Mayer PS, De Silva C, Meyer-Kornblum M, Kötschau D, Tennstedt P, Huang J, Gerhäuser C, Mader M, Kurtz S, Sirma H, Saad F, Steuber T, Graefen M, Plass C, Sauter G, Simon R, Minner S, Schlomm T: genomic deletion of PTEN is associated with tumor progression and early PSA recurrence in ERG fusion-positive and fusion-negative prostate cancer. Am J Pathol 2012;181:401-412.

-80 Antonarakis ES, Keizman D, Zhang Z, Gurel B, Lotan TL, Hicks JL, Fedor HL, Carducci MA, De Marzo AM, Eisenberger MA: An immunohistochemical signature comprising PTEN, MYC, and Ki67 predicts progression in prostate cancer patients receiving adjuvant docetaxel after prostatectomy. Cancer 2012;118:6063-6071.

-81 Hoogland AM, Jenster G, van Weerden WM, Trapman J, van der Kwast T, Roobol MJ, Schröder FH, Wildhagen MF, van Leenders GJ: ERG immunohistochemistry is not predictive for PSA recurrence, local recurrence or overall survival after radical prostatectomy for prostate cancer. Mod Pathol 2012;25:471-479.

82 Minner S, Luebke AM, Kluth M, Bokemeyer C, Jänicke F, Izbicki J, Schlomm T, Sauter G, Wilczak W: High level of Ets-related gene expression has high specificity for prostate cancer: a tissue microarray study of 11,483 cancers. Histopathology 2012;61:445-453. 
83 Chen JH, He HC, Jiang FN, Militar J, Ran PY, Qin GQ, Cai C, Chen XB, Zhao J, Mo ZY, Chen YR, Zhu JG, Liu X, Zhong WD: Analysis of the specific pathways and networks of prostate cancer for gene expression profiles in the Chinese population. Med Oncol 2012;29:1972-1984.

-84 Agell L, Hernández S, Nonell L, Lorenzo M, Puigdecanet E, de Muga S, Juanpere N, Bermudo R, Fernández PL, Lorente JA, Serrano S, Lloreta J: A 12-gene expression signature is associated with aggressive histological in prostate cancer: SEC14L1 and TCEB1 genes are potential markers of progression. Am J Pathol 2012;181: 1585-1594.

-85 Liu DF, Wu JT, Wang JM, Liu QZ, Gao ZL, Liu YX: MicroRNA expression profile analysis reveals diagnostic biomarker for human prostate cancer. Asian Pac J Cancer Prev 2012;13:3313-3317.

-86 Talagas M, Uguen A, Garlantezec R, Fournier G, Doucet L, Gobin E, Marcorelles P, Volant A, DE Braekeleer M: VEGFR1 and NRP1 endothelial expressions predict distant relapse after radical prostatectomy in clinically localized prostate cancer. Anticancer Res 2013;33:2065-2075.

87 Bruchmann A, Roller C, Walther TV, Schäfer G, Lehmusvaara S, Visakorpi T, Klocker H, Cato AC, Maddalo D: Bcl-2 associated athanogene 5 (Bag5) is overexpressed in prostate cancer and inhibits ER-stress induced apoptosis. BMC Cancer 2013;13:96.

88 Sethi S, Kong D, Land S, Dyson G, Sakr WA, Sarkar FH: Comprehensive molecular oncogenomic profiling and miRNA analysis of prostate cancer. Am J Transl Res 2013;5:200-211.

-89 Altintas DM, Allioli N, Decaussin M, de Bernard S, Ruffion A, Samarut J, Vlaeminck-Guillem V: Differentially expressed androgen-regulated genes in androgen-sensitive tissues reveal potential biomarkers of early prostate cancer. PLoS One 2013;8:e66278.

90 Borren A, Groenendaal G, van der Groep P, Moman MR, Boeken Kruger AE, van Der Heide UA, Jonges TN, van Diest PJ, van Vulpen M, Philippens ME: Expression of hypoxia-inducible factor- $1 \alpha$ and $-2 \alpha$ in whole-mount prostate histology: relation with dynamic contrast-enhanced MRI and Gleason score. Oncol Rep 2013;29: 2249-2254.

91 Shang Y, Zhu Z: Gp78 is specifically expressed in human prostate cancer rather than normal prostate tissue. J Mol Histol 2013;44:653-659.

92 de Resende MF, Chinen LT, Vieira S, Jampietro J, da Fonseca FP, Vassallo J, Campos LC, Guimarães GC, Soares FA, Rocha RM: Prognostication of OCT4 isoform expression in prostate cancer. Tumour Biol 2013;34:26652673.

-93 Mohsenzadegan M, Madjd Z, Asgari M, Abolhasani M, Shekarabi M, Taeb J, Shariftabrizi A: Reduced expression of NGEP is associated with high-grade prostate cancers: a tissue microarray analysis. Cancer Immunol Immunother 2013;62:1609-1618.

94 Slezak J, Truong M, Huang W, Jarrard D: HP1gamma expression is elevated in prostate cancer and is superior to Gleason score as a predictor of biochemical recurrence after radical prostatectomy. BMC Cancer 2013;13: 148.

$\$ 95$ Erho N, Crisan A, Vergara IA, Mitra AP, Ghadessi M, Buerki C, Bergstralh EJ, Kollmeyer T, Fink S, Haddad Z, Zimmermann B, Sierocinski T, Ballman KV, Triche TJ, Black PC, Karnes RJ, Klee G, Davicioni E, Jenkins RB: Discovery and validation of a prostate cancer genomic classifier that predicts early metastasis following radical prostatectomy. PLoS One 2013;8:e66855.

$\checkmark 96$ Amankwah EK, Anegbe E, Park H, Pow-Sang J, Hakam A, Park JY: miR-21, miR-221 and miR-222 expression and prostate cancer recurrence among obese and non-obese cases. Asian J Androl 2013;15:226-230.

-97 Song H, Liu Y, Pan J, Zhao ST: Expression profile analysis reveals putative prostate cancer-related microRNAs. Genet Mol Res 2013;12:4934-4943.

-98 Hernandez-Cueto A, Hernandez-Cueto D, Antonio-Andres G, Mendoza-Marin M, Jimenez-Gutierrez C, SandovalMejia AL, Mora-Campos R, Gonzalez-Bonilla C, Vega MI, Bonavida B, Huerta-Yepez S: Death receptor 5 expression is inversely correlated with prostate cancer progression. Mol Med Rep 2014;10:2279-2286.

99 Zhang H, Cheng S, Wang A, Ma H, Yao B, Qi C, Liu R, Qi S, Xu Y: Expression of RABEX-5 and its clinical significance in prostate cancer. J Exp Clin Cancer Res 2014;33:31.

100 Al Bashir S, Alshalalfa M, Hegazy SA, Dolph M, Donnelly B, Bismar TA: Cysteine-rich secretory protein 3 (CRISP3), ERG and PTEN define a molecular subtype of prostate cancer with implication to patients' prognosis. J Hematol Oncol 2014; 7:21.

101 Witte LP, Teitsma CA, de la Rosette JJ, Michel MC: Muscarinic receptor subtype mRNA expression in the human prostate: association with age, pathological diagnosis, prostate size, or potentially interfering medications? Naunyn Schmiedebergs Arch Pharmacol 2014;387:207-214.

102 Eguchi FC, Faria EF, Scapulatempo Neto C, Longatto-Filho A, Zanardo-Oliveira C, Taboga SR, Campos SG: The role of TMPRSS2:ERG in molecular stratification of PCa and its association with tumor aggressiveness: a study in Brazilian patients. Sci Rep 2014;4:5640.

103 Bismar TA, Alshalalfa M, Petersen LF, Teng LH, Gerke T, Bakkar A, Al-Mami A, Liu S, Dolph M, Mucci LA, Alhajj $\mathrm{R}$ : Interrogation of ERG gene rearrangements in prostate cancer identifies a prognostic 10-gene signature with relevant implication to patients' clinical outcome. BJU Int 2014;113:309-319.

104 Kneitz B, Krebs M, Kalogirou C, Schubert M, Joniau S, van Poppel H, Lerut E, Kneitz S, Scholz CJ, Ströbel P, Gessler M, Riedmiller H, Spahn M: Survival in patients with high-risk prostate cancer is predicted by miR-221, which regulates proliferation, apoptosis, and invasion of prostate cancer cells by inhibiting IRF2 and SOCS3. Cancer Res 2014;74:2591-2603. 
105 Tsourlakis M, Khosrawi P, Weigand P, Kluth M, Hube-Magg C, Minner S, Koop C, Graefen M, Heinzer H, Wittmer C, Sauter G, Krech T, Wilczak W, Huland H, Simon R, Schlomm T, Steurer S: VEGFR-1 overexpression identifies a small subgroup of aggressive prostate cancers in patients treated by prostatectomy. Int J Mol Sci 2015;16: 8591-8606.

106 Kim SH, Kim SH, Joung JY, Lee GK, Hong EK, Kang KM, Yu A, Nam BH, Chung J, Seo HK, Park WS, Lee KH: Overexpression of ERG and wild-type PTEN are associated with favorable clinical prognosis and low biochemical recurrence in prostate cancer. PLoS One 2015;10:e0122498.

107 Chen J, Wang J, Cui X, Liu Y, Yin L, Li Y, Chen L, Xu D, Gao Y: Positive nin one binding protein expression predicts poor outcome in prostate cancer. Mol Med Rep 2015;11:2671-2676.

108 Leyten GH, Hessels D, Smit FP, Jannink SA, de Jong H, Melchers WJ, Cornel EB, de Reijke TM, Vergunst H, Kil P, Knipscheer BC, Hulsbergen-van de Kaa CA, Mulders PF, van Oort IM, Schalken JA: Identification of a candidate gene panel for the early diagnosis of prostate cancer. Clin Cancer Res 2015;21:3061-3070.

$\checkmark 109$ Karatas OF, Guzel E, Duz MB, Ittmann M, Ozen M: The role of ATP-binding cassette transporter genes in the progression of prostate cancer. Prostate 2016;76:434-444.

110 Myers JS, von Lersner AK, Robbins CJ, Sang QX: Differentially expressed genes and signature pathways of human prostate cancer. PLoS One 2015;10:e0145322.

111 Gerke TA, Martin NE, Ding Z, Nuttall EJ, Stack EC, Giovannucci E, Lis RT, Stampfer MJ, Kantoff PW, Parmigiani G, Loda M, Mucci LA: Evaluating a 4-marker signature of aggressive prostate cancer using time-dependent AUC. Prostate 2015;75:1926-1933.

112 Stelloo S, Nevedomskaya E, van der Poel HG, de Jong J, van Leenders GJ, Jenster G, Wessels LF, Bergman AM, Zwart W: Androgen receptor profiling predicts prostate cancer outcome. EMBO Mol Med 2015;7:1450-1464.

113 Väänänen RM, Ochoa NT, Boström PJ, Taimen P, Pettersson K: Altered PCA3 and TMPRSS2-ERG expression in histologically benign regions of cancerous prostates: a systematic, quantitative mRNA analysis in five prostates. BMC Urol 2015;15:88.

114 Zhu J, Pan C, Jiang J, Deng M, Gao H, Men B, McClelland M, Mercola D, Zhong WD, Jia Z: Six stroma-based RNA markers diagnostic for prostate cancer in European-Americans validated at the RNA and protein levels in patients in China. Oncotarget 2015;6:16757-16765.

-115 Robinson D, Van Allen EM, Wu YM, Schultz N, Lonigro RJ, Mosquera JM, Montgomery B, Taplin ME, Pritchard CC, Attard G, Beltran H, Abida W, Bradley RK, Vinson J, Cao X, Vats P, Kunju LP, Hussain M, Feng FY, Tomlins SA, Cooney KA, Smith DC, Brennan C, Siddiqui J, Mehra R, Chen Y, Rathkopf DE, Morris MJ, Solomon SB, Durack JC, Reuter VE, Gopalan A, Gao J, Loda M, Lis RT, Bowden M, Balk SP, Gaviola G, Sougnez C, Gupta M, Yu EY, Mostaghel EA, Cheng HH, Mulcahy H, True LD, Plymate SR, Dvinge H, Ferraldeschi R, Flohr P, Miranda S, Zafeiriou Z, Tunariu N, Mateo J, Perez-Lopez R, Demichelis F, Robinson BD, Schiffman M, Nanus DM, Tagawa ST, Sigaras A, Eng KW, Elemento O, Sboner A, Heath EI, Scher HI, Pienta KJ, Kantoff P, de Bono JS, Rubin MA, Nelson PS, Garraway LA, Sawyers CL, Chinnaiyan AM: Integrative clinical genomics of advanced prostate cancer. Cell 2015;161:1215-1228.

116 Zhao SG, Jackson WC, Kothari V, Schipper MJ, Erho N, Evans JR, Speers C, Hamstra DA, Niknafs YS, Nguyen PL, Schaeffer EM, Ross AE, Den RB, Klein EA, Jenkins RB, Davicioni E, Feng FY: High-throughput transcriptomic analysis nominates proteasomal genes as age-specific biomarkers and therapeutic targets in prostate cancer. Prostate Cancer Prostatic Dis 2015;18:229-236.

$\checkmark 117$ Alshalalfa M, Crisan A, Vergara IA, Ghadessi M, Buerki C, Erho N, Yousefi K, Sierocinski T, Haddad Z, Black PC, Karnes RJ, Jenkins RB, Davicioni E: Clinical and genomic analysis of metastatic prostate cancer progression with a background of postoperative biochemical recurrence. BJU Int 2015;116:556-567.

118 Wang X, Wen J, Li R, Qiu G, Zhou L, Wen X: Gene expression profiling analysis of castration-resistant prostate cancer. Med Sci Monit 2015;21:205-212.

-119 Prensner JR, Zhao S, Erho N, Schipper M, Iyer MK, Dhanasekaran SM, Magi-Galluzzi C, Mehra R, Sahu A, Siddiqui J, Davicioni E, Den RB, Dicker AP, Karnes RJ, Wei JT, Klein EA, Jenkins RB, Chinnaiyan AM, Feng FY: RNA biomarkers associated with metastatic progression in prostate cancer: a multi-institutional high-throughput analysis of SChLAP1. Lancet Oncol 2014;15:1469-1480.

120 Moradi Sardareh H, Goodarzi MT, Yadegar-Azari R, Poorolajal J, Mousavi-Bahar SH, Saidijam M: Prostate cancer antigen 3 gene expression in peripheral blood and urine sediments from prostate cancer and benign prostatic hyperplasia patients versus healthy individuals. Urol J 2014;11:1952-1958.

121 Debiais-Delpech C, Godet J, Pedretti N, Bernard FX, Irani J, Cathelineau X, Cussenot O, Fromont G: Expression patterns of candidate susceptibility genes HNF1 $\beta$ and CtBP2 in prostate cancer: association with tumor progression. Urol Oncol 2014;32:426-432.

-122 Mengual L, Ars E, Lozano JJ, Burset M, Izquierdo L, Ingelmo-Torres M, Gaya JM, Algaba F, Villavicencio H, Ribal MJ, Alcaraz A: Gene expression profiles in prostate cancer: identification of candidate non-invasive diagnostic markers. Actas Urol Esp 2014;38:143-149.

-123 Peng Z, Skoog L, Hellborg H, Jonstam G, Wingmo IL, Hjälm-Eriksson M, Harmenberg U, Cedermark GC, Andersson K, Ahrlund-Richter L, Pramana S, Pawitan Y, Nistér M, Nilsson S, Li C: An expression signature at diagnosis to estimate prostate cancer patients' overall survival. Prostate Cancer Prostatic Dis 2014;17:81-90.

124 Zhai W, Yao XD, Xu YF, Peng B, Zhang HM, Liu M, Huang JH, Wang GC, Zheng JH: Transcriptome profiling of prostate tumor and matched normal samples by RNA-Seq. Eur Rev Med Pharmacol Sci 2014;18:1354-1360. 
125 Rabiau N, Dantal Y, Guy L, Ngollo M, Dagdemir A, Kemeny JL, Terris B, Vieillefond A, Boiteux JP, Bignon YJ, Bernard-Gallon D: Gene panel model predictive of outcome in patients with prostate cancer. OMICS 2013;17: 407-413.

126 Han ZD, Zhang YQ, He HC, Dai QS, Qin GQ, Chen JH, Cai C, Fu X, Bi XC, Zhu JG, Liao DJ, Lu XP, Mo ZY, Zhu YP, Zhong WD: Identification of novel serological tumor markers for human prostate cancer using integrative transcriptome and proteome analysis. Med Oncol 2012;29:2877-2888.

127 Grisanzio C, Werner L, Takeda D, Awoyemi BC, Pomerantz MM, Yamada H, Sooriakumaran P, Robinson BD, Leung R, Schinzel AC, Mills I, Ross-Adams H, Neal DE, Kido M, Yamamoto T, Petrozziello G, Stack EC, Lis R, Kantoff PW, Loda M, Sartor O, Egawa S, Tewari AK, Hahn WC, Freedman ML: Genetic and functional analyses implicate the NUDT11, HNF1B, and SLC22A3 genes in prostate cancer pathogenesis. Proc Natl Acad Sci USA 2012;109:11252-11257.

128 Zhong WD, Qin GQ, et al: SOXs in human prostate cancer: implication as progression and prognosis factors. BMC Cancer 2012;12:248.

129 Derosa CA, Furusato B, Shaheduzzaman S, Srikantan V, Wang Z, Chen Y, Seifert M, Ravindranath L, Young D, Nau M, Dobi A, Werner T, McLeod DG, Vahey MT, Sesterhenn IA, Srivastava S, Petrovics G: Elevated osteonectin/SPARC expression in primary prostate cancer predicts metastatic progression. Prostate Cancer Prostatic Dis 2012;15:150-156.

130 Armstrong K, Ahmad I, Kalna G, Tan SS, Edwards J, Robson CN, Leung HY: Upregulated FGFR1 expression is associated with the transition of hormone-naive to castrate-resistant prostate cancer. Br J Cancer 2011;105: 1362-1369.

131 Long Q, Johnson BA, Osunkoya AO, Lai YH, Zhou W, Abramovitz M, Xia M, Bouzyk MB, Nam RK, Sugar L, Stanimirovic A, Williams DJ, Leyland-Jones BR, Seth AK, Petros JA, Moreno CS: Protein-coding and microRNA biomarkers of recurrence of prostate cancer following radical prostatectomy. Am J Pathol 2011;179:46-54.

132 Soni A, Bansal A, Singh LC, Mishra AK, Majumdar M, Regina T, Mohanty NK, Saxena S: Gene expression profile and mutational analysis of DNA mismatch repair genes in carcinoma prostate in Indian population. OMICS 2011;15:319-324.

133 Jia Z, Wang Y, Sawyers A, Yao H, Rahmatpanah F, Xia XQ, Xu Q, Pio R, Turan T, Koziol JA, Goodison S, Carpenter P, Wang-Rodriguez J, Simoneau A, Meyskens F, Sutton M, Lernhardt W, Beach T, Monforte J, McClelland M, Mercola D: Diagnosis of prostate cancer using differentially expressed genes in stroma. Cancer Res 2011;71: 2476-2487.

134 Maresh EL, Mah V, Alavi M, Horvath S, Bagryanova L, Liebeskind ES, Knutzen LA, Zhou Y, Chia D, Liu AY, Goodglick L: Differential expression of anterior gradient gene AGR2 in prostate cancer. BMC Cancer 2010;10: 680.

135 Gorlov IP, Sircar K, Zhao H, Maity SN, Navone NM, Gorlova OY, Troncoso P, Pettaway CA, Byun JY, Logothetis CJ: Prioritizing genes associated with prostate cancer development. BMC Cancer 2010;10:599.

-136 Romanuik TL, Ueda T, Le N, Haile S, Yong TM, Thomson T, Vessella RL, Sadar MD: Novel biomarkers for prostate cancer including noncoding transcripts. Am J Pathol 2009;175:2264-2276.

$\checkmark 137$ Antunes AA, Leite KR, Reis ST, Sousa-Canavez JM, Camara-Lopes LH, Dall'oglio MF, Srougi M: GREB1 tissue expression is associated with organ-confined prostate cancer. Urol Oncol 2012;30:16-20.

138 Endo T, Uzawa K, Suzuki H, Tanzawa H, Ichikawa T: Characteristic gene expression profiles of benign prostatic hypertrophy and prostate cancer. Int J Oncol 2009;35:499-509.

139 Qian DZ, Huang CY, O’Brien CA, Coleman IM, Garzotto M, True LD, Higano CS, Vessella R, Lange PH, Nelson PS, Beer TM: Prostate cancer-associated gene expression alterations determined from needle biopsies. Clin Cancer Res 2009;15:3135-3142.

140 Arencibia JM, Martín S, et al: Gene expression profiling reveals overexpression of TSPAN13 in prostate cancer. Int J Oncol 2009;34:457-463.

141 Nariculam J, Freeman A, Bott S, Munson P, Cable N, Brookman-Amissah N, Williamson M, Kirby RS, Masters J, Feneley M: Utility of tissue microarrays for profiling prognostic biomarkers in clinically localized prostate cancer: the expression of BCL-2, E-cadherin, Ki-67 and p53 as predictors of biochemical failure after radical prostatectomy with nested control for clinical and pathological risk factors. Asian J Androl 2009;11:109-118.

142 Alonso V, Neves AF, Marangoni K, Faria PC, Freschi AP, Capaneli AC, Meola J, Goulart LR: Gene expression profile in the peripheral blood of patients with prostate cancer and benign prostatic hyperplasia. Cancer Detect Prev 2009;32:336-337.

143 Thompson M, Lapointe J, Choi YL, Ong DE, Higgins JP, Brooks JD, Pollack JR: Identification of candidate prostate cancer genes through comparative expression-profiling of seminal vesicle. Prostate 2008;68:1248-1256.

144 Savli H, Szendröi A, Romics I, Nagy B: Gene network and canonical pathway analysis in prostate cancer: a microarray study. Exp Mol Med 2008;40:176-185.

145 Kosari F, Munz JMA, Savci-Heijink CD, Spiro C, Klee EW, Kube DM, Tillmans L, Slezak J, Karnes RJ, Cheville JC, Vasmatzis G: Identification of prognostic biomarkers for prostate cancer. Clin Cancer Res 2008;14:1734-1743.

146 Rizzi F, Belloni L, Crafa P, Lazzaretti M, Remondini D, Ferretti S, Cortellini P, Corti A, Bettuzzi S: A novel gene signature for molecular diagnosis of human prostate cancer by RT-qPCR. PLoS One 2008;3:e3617.

147 Furusato B, Shaheduzzaman S, Petrovics G, Dobi A, Seifert M, Ravindranath L, Nau ME, Werner T, Vahey M, McLeod DG, Srivastava S, Sesterhenn IA: Transcriptome analyses of benign and malignant prostate epithelial cells in formalin-fixed paraffin-embedded whole-mounted radical prostatectomy specimens. Prostate Cancer Prostatic Dis 2008;11:194-197. 
148 Richardson AM, Woodson K, Wang Y, Rodriguez-Canales J, Erickson HS, Tangrea MA, Novakovic K, Gonzalez S, Velasco A, Kawasaki ES, Emmert-Buck MR, Chuaqui RF, Player A: Global expression analysis of prostate cancer-associated stroma and epithelia. Diagn Mol Pathol 2007;16:189-197.

149 Bibikova M, Chudin E, Arsanjani A, Zhou L, Garcia EW, Modder J, Kostelec M, Barker D, Downs T, Fan JB, WangRodriguez J: Expression signatures that correlated with Gleason score and relapse in prostate cancer. Genomics 2007;89:666-672.

150 Schmidt U, Fuessel S, Koch R, Baretton GB, Lohse A, Tomasetti S, Unversucht S, Froehner M, Wirth MP, Meye A: Quantitative multi-gene expression profiling of primary prostate cancer. Prostate 2006;66:1521-1534.

151 Stavropoulou P, Gregorakis AK, Plebani M, Scorilas A: Expression analysis and prognostic significance of human kallikrein 11 in prostate cancer. Clin Chim Acta 2005;357:190-195.

152 Ashida S, Nakagawa H, Katagiri T, Furihata M, Iiizumi M, Anazawa Y, Tsunoda T, Takata R, Kasahara K, Miki T, Fujioka T, Shuin T, Nakamura Y: Molecular features of the transition from prostatic intraepithelial neoplasia (PIN) to prostate cancer: genome-wide gene-expression profiles of prostate cancers and PINs. Cancer Res 2004;64:5963-5972.

153 Latil A, Bièche I, Chêne L, Laurendeau I, Berthon P, Cussenot O, Vidaud M. Gene expression profiling in clinically localized prostate cancer: a four-gene expression model predicts clinical behavior. Clin Cancer Res 2003; 9:5477-5485.

154 Ulahannan D, Kovac MB, Mulholland PJ, Cazier JB, Tomlinson I: Technical and implementation issues in using next-generation sequencing of cancers in clinical practice. Br J Cancer 2013;109:827-835.

155 Sboner A, Demichelis F, Calza S, Pawitan Y, Setlur SR, Hoshida Y, Perner S, Adami HO, Fall K, Mucci LA, Kantoff PW, Stampfer M, Andersson SO, Varenhorst E, Johansson JE, Gerstein MB, Golub TR, Rubin MA, Andrén O: Molecular sampling of prostate cancer: a dilemma for predicting disease progression. BMC Med Genomics 2010;3:8.

156 Habibian DJ, Liu CC, Dao A, Kosinski KE, Katz AE: Imaging characteristics of prostate cancer patients who discontinued active surveillance on 3-T multiparametric prostate MRI. AJR Am J Roentgenol 2017;208:564569.

157 Gudmundsson J, Sulem P, Gudbjartsson DF, Blondal T, Gylfason A, Agnarsson BA, Benediktsdottir KR, Magnusdottir DN, Orlygsdottir G, Jakobsdottir M, Stacey SN, Sigurdsson A, Wahlfors T, Tammela T, Breyer JP, McReynolds KM, Bradley KM, Saez B, Godino J, Navarrete S, Fuertes F, Murillo L, Polo E, Aben KK, van Oort IM, Suarez BK, Helfand BT, Kan D, Zanon C, Frigge ML, Kristjansson K, Gulcher JR, Einarsson GV, Jonsson E, Catalona WJ, Mayordomo JI, Kiemeney LA, Smith JR, Schleutker J, Barkardottir RB, Kong A, Thorsteinsdottir U, Rafnar T, Stefansson K: Genome-wide association and replication studies identify four variants associated with prostate cancer susceptibility. Nat Genet 2009;41:1122-1126.

$>158$ Thomas G, Jacobs KB, Yeager M, Kraft P, Wacholder S, Orr N, Yu K, Chatterjee N, Welch R, Hutchinson A Crenshaw A, Cancel-Tassin G, Staats BJ, Wang Z, Gonzalez-Bosquet J, Fang J, Deng X, Berndt SI, Calle EE, Feigelson HS, Thun MJ, Rodriguez C, Albanes D, Virtamo J, Weinstein S, Schumacher FR, Giovannucci E, Willett WC, Cussenot O, Valeri A, Andriole GL, Crawford ED, Tucker M, Gerhard DS, Fraumeni JF Jr, Hoover R, Hayes RB, Hunter DJ, Chanock SJ: Multiple loci identified in a genome-wide association study of prostate cancer. Nat Genet 2008;40:310-315.

159 Hazelett DJ, Rhie SK, Gaddis M, Yan C, Lakeland DL, Coetzee SG; Ellipse/GAME-ON Consortium; Practical Consortium, Henderson BE, Noushmehr H, Cozen W, Kote-Jarai Z, Eeles RA, Easton DF, Haiman CA, Lu W, Farnham PJ, Coetzee GA: Comprehensive functional annotation of 77 prostate cancer risk loci. PLoS Genet 2014;10:e1004102.

160 Shui IM, Lindström S, Kibel AS, Berndt SI, Campa D, Gerke T, Penney KL, Albanes D, Berg C, Bueno-de-Mesquita HB, Chanock S, Crawford ED, Diver WR, Gapstur SM, Gaziano JM, Giles GG, Henderson B, Hoover R, Johansson M, Le Marchand L, Ma J, Navarro C, Overvad K, Schumacher FR, Severi G, Siddiq A, Stampfer M, Stevens VL, Travis RC, Trichopoulos D, Vineis P, Mucci LA, Yeager M, Giovannucci E, Kraft P: Prostate cancer (PCa) risk variants and risk of fatal PCa in the National Cancer Institute Breast and Prostate Cancer Cohort Consortium. Eur Urol 2014;65:1069-1075. 